<総説 >

\title{
統合失調症の発達障害仮説と必須脂肪酸の関連についての考察
}

\author{
吉川武男、渡辺明子、前川素子 \\ 独立行政法人理化学研究所脳科学総合研究センター \\ 广351-0198 埼玉県和光市広沢2-1 \\ TEL: 048-467-5968.FAX: 048-467-7462、E-mail: takeo@brain.riken.jp \\ キーワード : 統合失調症、エンドフェノタイプ、プレパルス抑制、量的形質遺伝子座解析、
} $F A B P 7$ 遺伝子

\section{Neurodevelopmental hypothesis of schizophrenia and involvement of essential fatty acid}

\author{
Takeo Yoshikawa' ${ }^{1)}$, Akiko Watanabe ${ }^{1)}$, Motoko Maekawa ${ }^{1)}$ \\ ${ }^{1)}$ RIKEN Brain Science Institute \\ 2-1 Hirosawa, Wako, Saitama 351-00198, Japan
}

\section{Summary}

Deficits in prepulse inhibition (PPI) are a biological marker for schizophrenia. To unravel the mechanisms that control PPI, we performed quantitative trait loci (QTL) analysis, on $1010 \mathrm{~F} 2$ mice derived by crossing C57BL/6 (B6) animals that show high PPI with $\mathrm{C} 3 \mathrm{H} / \mathrm{He}(\mathrm{C} 3)$ animals that show low PPI. We detected 6 major loci for PPI. A promising candidate on the chromosome 10-QTL was Fabp 7 (fatty acid binding protein 7, brain), a gene with functional links to the NMDA receptor and expression in neural stem/ progenitor cells in developmental stage. Fabp7-deficient mice indeed showed decreased PPI. A quantitative complementation test supported $F a b p 7$ as a potential PPI-QTL gene. Disruption of Fabp 7 attenuated neurogenesis in vivo. Human $F A B P 7$ showed genetic association with schizophrenia. FABP7 is known to have high affinity for polyunsaturated fatty acids, in particular docosahexaenoic acid. These results suggest that FABP7 plays a novel and crucial role, linking the NMDA, neurodevelopmental and nutritional issues of schizophrenia pathology.

Keywords: schizophrenia, endophenotype, prepulse inhibition, quantitative trait loci (QTL), FABP7 


\section{1.はじめに}

統合失調症は、気分障害 (うつ病、躁うつ病) と並んで二大精神疾患と言われている。 生涯䍜患率は、国、地域、時代に関係なく、一般人口の約 $1 \%$ と言われているように、 決して珍しい疾患ではない ${ }^{1}$ 。思春期以降に好発し、症状としては幻聴や妄想 (陽性症 状と呼ばれる)、および感情の平板化や社会的引きこもり（陰性症状）などが現れ、ド 一パミン受容体をブロックする作用のある向精神薬を服用することで寛解に至ることが 多い。現在利用できる治療薬がドーパミン受容体に㗢くことは分かっているが、本当の 原因はどこにあるかは不明であり、よって根本的な治療薬の開発や、原因の理解に基 づいた予防法の確立が求められている。後述するように、統合失調症の診断に関して は客観的な方法がないため、「統合失調症」という1つの病名の中には、いろいろな原 因の疾患が混在している可能性が大きい2)。

著者らは、統合失調症に関連のある生理学的指標の責任遺伝子を探索する中で、 必須脂肪酸の結合・運搬・利用に役割を果たす遺伝子を同定した。統合失調症の原因 としては、脳の発生時期の侵襲の問題 (栄盖学的観点も含めて) や多価不飽和脂肪酸 の関与が報告されているので、我々が同定した分子は統合失調症の原因・病態生理と 多価不飽和脂肪酸を結ぶ重要なものではないかと考え、背景も含めてこの分子に焦点 を当てて統合失調症との関連を考えてみたい。

\section{2. エンドフェノタイプ}

統合失調症の症状の出方や経過は、患者さんによって大きなバリエーションがある。 このため19世紀までは精神疾患の病名はたくさんあり氾濫していた。1900年前後にな って、ドイツの精神医学者エミール・クレペリン（アルツハイマーと同世代の人である）が、 精神疾患をそのときの横断的な症状ばかりでなく、経過という縦断的な観点を加えて分 類し、今日まで用いられている二大精神疾患の概念を打ち立てた。しかし統合失調症 には特異的な“バイオマーカー”や客観的な検査方法があるわけでなく、今でも患者 さんの内的体験の陳述や周囲の人の観察情報に頼っているのが現状である。そこで、 2000年代に入ってからエンドフェノタイプ (中間表現型とも言われる) という概念が脚 光を浴びるようになった ${ }^{3)}$ 。これは、統合失調症に100\%特異的ではないが、健常人と 比べると統合失調症に多く観察される生理学的あるいは生化学的所見を指し、薬や症 状に影響されない一種の理想的なパラメーターを想定している。統合失調症の遺伝子 解析が難航する中、エンドフェノタイプを対象に遺伝学的研究を進めた方が、対象の 均一性が上がり、より明確な結果が出やすいのではないかという発想で出てきた概念 である。 


\section{3. プレパルス抑制 (PPI)}

これは、統合失調症のエンドフェノタイプの1つと考えられているもので、実験動物 でもヒトでも同じように測定できる利点がある。大きな音 (パルス音) をヒトや動物に突 然 (パルス的に) に聞かせると、驚愕反応が生じる。平たく言えばびっくりして筋収縮 が起こる現象である。ところが、大きな音の前に驚愕反応が生じない程度の小さな暗プ レパルス音）を100 msec前に挿入すると、パルス音だけのときと比べて驚愕反応の大き さが減弱する (図1)。この現象をプレパルス抑制 (prepulse inhibition: PPI) と呼んで いるが、統合失調症の患者さんやその家族では、PPIが働きにくいことが報告されてい る ${ }^{4)}$ 。PPIが起こるメカニズムとしては、プレパルス音を聞いたときに生体がそちらに注 意を集中し、後からくるパルス音を「感覚フィルター」で遮断してしまうからであると考 えられている。よって、PPI機能は感覚フィルター機能を反映していると考えられている。 これは、「カクテルパーティー効果」と同質ものと言える。統合失調症の患者さんは、 人混みの中ではいろいろな刺激がいっぺんに入ってきて集中困難や易疲労性を示しや すいという事実とも関係する。
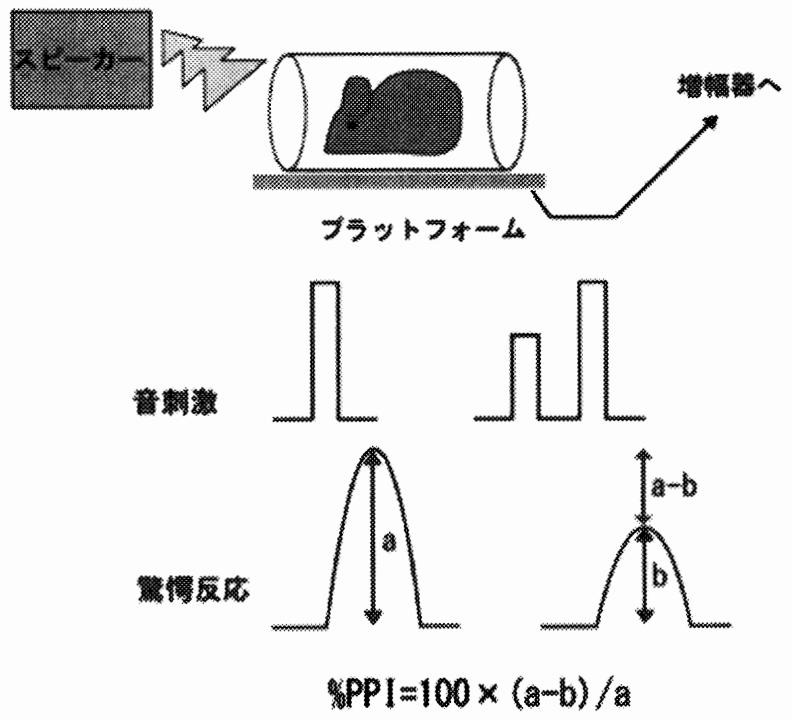

Figure 1. Illustration of prepulse inhibition measurement

PPI is shown in \% of startle suppression evoked by preceded prepulse.

\section{4. 量的形質遗伝子座解析 (QTL解析)}

PPIの程度は、原則的に $0 \%$ から $100 \%$ \%での連続した值を取り得る。このような量 的形質は、身長、体重、血糖値 (糖尿病)、血圧 (高血圧症) などと同じく複数の遺伝 子によって制御されている。我々は、マウスを用いてPPIを制御している遺伝子を同定 できれば、それらはヒト統合失調症の有力な感受性遺伝子として解析するに值するの 
ではないかと考え研究を行った。量的形質に関与する遺伝子のある場所を探す方法と して、量的形質遺伝子座解析 (Quantitative Trait Loci Analysis: QTL解析) がある。 これをマウスに適応する場合、以下の手順となる (図2）：

（1）マウス近交系のうち、PPIの大きさについて両極端の值を示すものを探す。

（2）それら両極端の2系統を掛け合わせて、F2世代(孫の世代)の個体を作成する。

（3） F2世代の個体について、1匹ずつPPIの值を調べ、かつ全ゲノムに渡って遺伝 子型を調べる(ある染色体の部位がF0世代のどちらの系統から由来しているかと いうこと)。

（4） PPIの值と遺伝子型データをもとに連鎖解析をすると、責任遺伝子が存在して いる染色体部位が判明する。

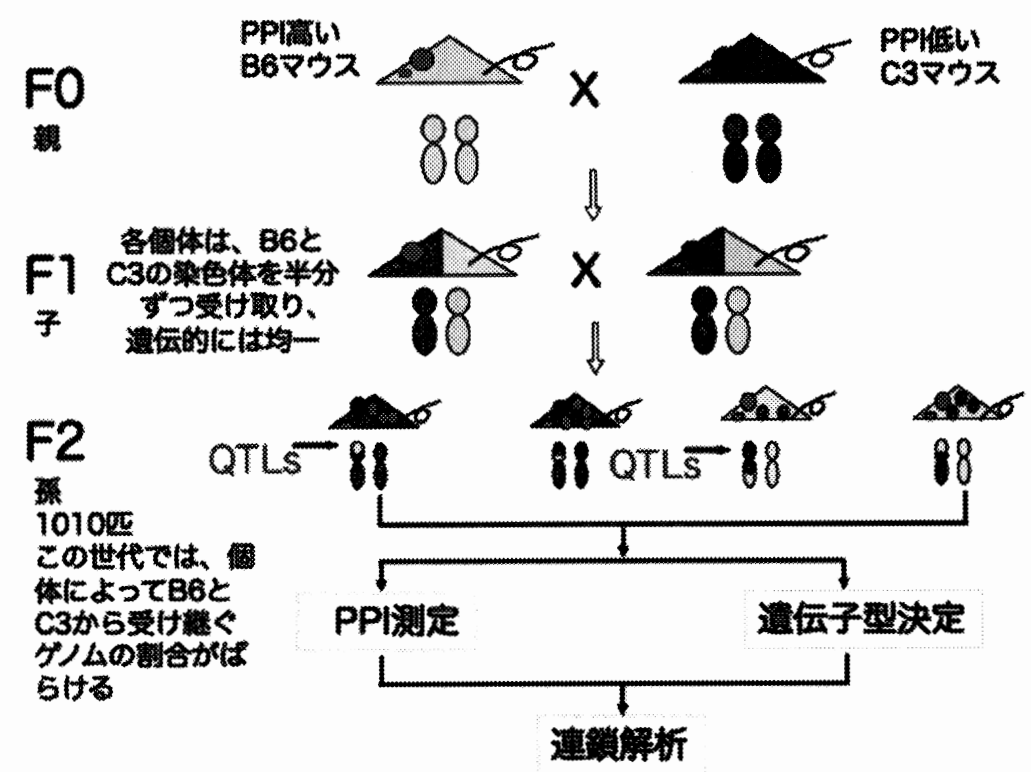

Figure 2. Method of quantitative trait loci analysis

（1）について、我々はC57BL/6 (B6), DBA/2, BALB/c, C3H/He (C3)の4系統を 検討したところ、B6が最も高いPPIを、そしてC3が最も低いPPIを示したのでこの2系 統をF0として用いた。PPIテストをするときは、通常何種類かのプレパルスレベルを1つ のセッションで混ぜることになっており、我々は $74,78,82,86 \mathrm{~dB}$ のプレパルス音圧を用 いた。パルス音圧は $120 \mathrm{~dB}$ 用いた。QTL解析の結果を図 3 に示す5)。縦軸はロッド スコア（lod score）の值で、この值が高い程その染色体部位に責任遺伝子が存在する 可能性が高くなる。図3で、ロッドスコアが3.4前後のところに横線が引いてあるが、ピ 一クがこの線を越えた部位に責任遺伝子がある可能性は $95 \%$ 以上であることを示す。 
よって、今回用いたマウスに限って言えばPPIを制御しているメジャーな遺伝子は少なく とも 6 個あると言える (図 3)。その中でも、染色体10番のピークが一番高くシャープで あった。プレパルス音圧レベルにかかわらずピークが同じ場所にあるのは、科学的にも 合理性がある。異なったプレパルスレベルに対してPPIを制御する遺伝子が異なってい るとは考えにくいからである。

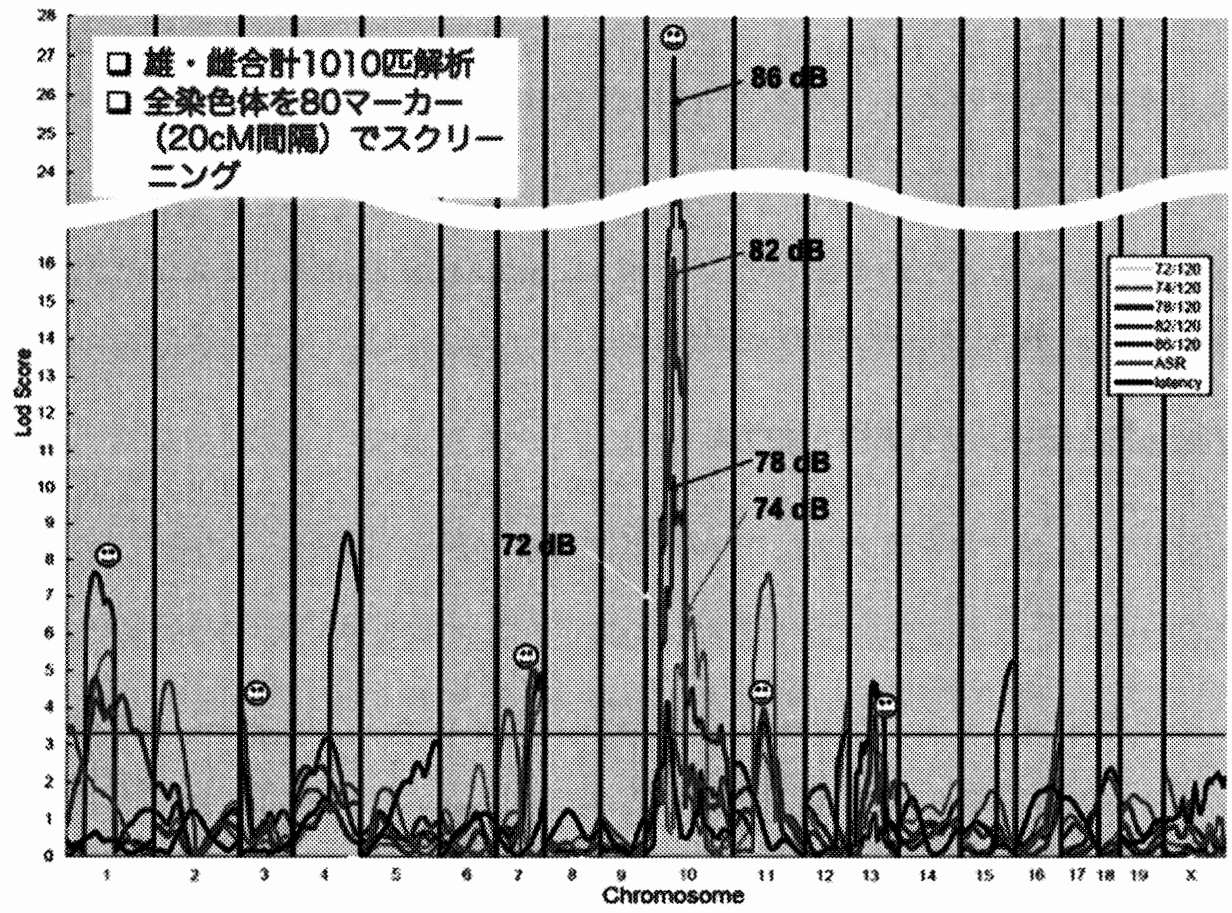

Figure 3. Lod score plots for the whole genome The results for PPI at 5 different prepulse levels $(72,74,78,82$ and $86 \mathrm{~dB})$, ASR (acoustic startle reflex, startle stimulus was $120 \mathrm{~dB}$ ) and latency are shown. Smile marks show six genome-wide significant PPI lod score peaks.

\section{Fabp7遺伝子}

染色体10番のピークの $95 \%$ 信頼区間 (95\%の確率で責任遺伝子が存在する領域) には約30個の遺伝子があったが、その中でも我々は以下の理由でFabp7 (brain type fatty acid binding proteinともいう)に注目した。

・脳に発現が多く見られ、多価不飽和脂肪酸結合タンパク質をコードしており、多価 不飽和脂肪酸のうちでもドコサヘキサエン酸 (DHA) に親和性が高いとin vitroで 報告されている ${ }^{6)}$ 。

・統合失調症の発症脆弱性として、脳の発達期の微細な異常が基底にあるのでは 
ないかと種々のデータから言われている（統合失調症の神経発達障害仮説） ${ }^{7}$ 。 FABP7は、特に脳の発達期に多く発現がみられる。

・ 統合失調症と多価不飽和脂肪酸結合の関連は繰り返し報告されてきた ${ }^{8)}$ 。

そこで、B6とC3のゲノムでFabp7遺伝子領域のシークエンスをして塩基配列の違い を探索したが、調べた限りでは違いはなかった。Fabp7に限らずFabp遺伝子ファミリ ーメンバー [現在までにFabp12まで報告されている ${ }^{9)}$ ] は、発現を調節するのにコア プロモーターだけではなく、ゲノム上に複数発現調節領域（例えばエンハンサー）が 散在していることが推定されているが、それらについては具体的に殆ど判明していな い"10)。そこで我々は別のアプローチを取り、Fabp7がマウス染色体10番上のPPI責任 遺伝子（の1つ）かどうかを調べた。それはcomplementation testという遺伝学的 方法であるが、詳細は文献を参照されたい"11)。

\section{Fabp7遺伝子ノックアウトマウス}

実際Fabp7ノックアウトマウスを作成しPPIを測定したところ、PPIの減弱が確認さ れた (図4)。なお、このマウスはPPIの異常の他に以下の特徵が認められた：

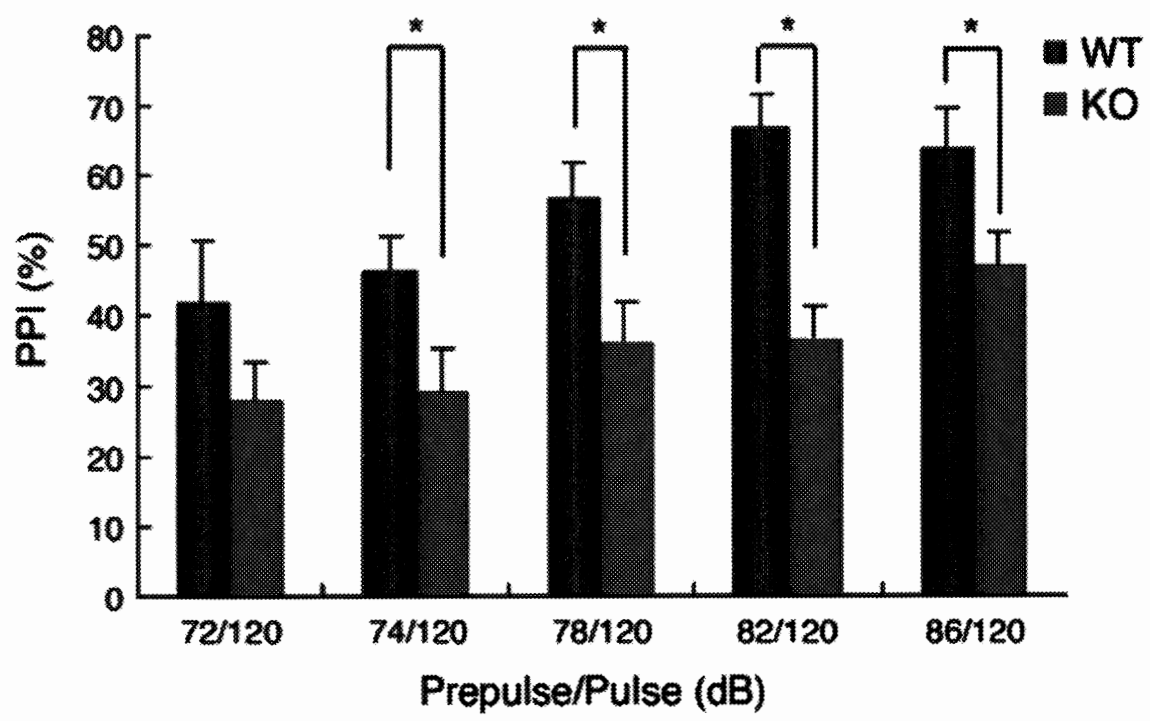

Figure 4. Analysis of PPI in Fabp7 knockout mouse

PPI (\%) between wild-type (WT, $\mathrm{n}=9: 6$ males and 3 females) and $F a b p 7$ (-/-) mice $(\mathrm{KO}, \mathrm{n}=12: 6$ males and 6 females). The values represent mean \pm S.E. $* P<0.05$ 
・ 外観および藏器の肉眼解剖的には正常で、成長も正常である。

- 統合失調症の薬物モデルとして使用されるMK-801 (NMDA受容体の非競合的阻 害薬である）の反復投与に対する過感受性が認められた5)。統合失調症の病因・病 態仮説としてNMDA神経伝達の低下も提唱されているが ${ }^{12)}$ 、この仮説にも適合す る。なお、電気生理学的解析では、このノックアウトマウスはDHAによるNMDA電 流の促進効果が障害されていた ${ }^{13)}$ 。このデータは、Fabp7とNMDA受容体の関連を さらに補強するものである。

- Fabp7は神経幹細胞/前駆細胞に発現が多く ${ }^{14)}$ 、神経新生に関与している可能性が 考えられた。よって、ノックアウトマウスの神経新生の程度を海馬の歯状回で検討し た。すると、野生型マウスと比較して神経新生能力が有意に低下していた（図 5)。
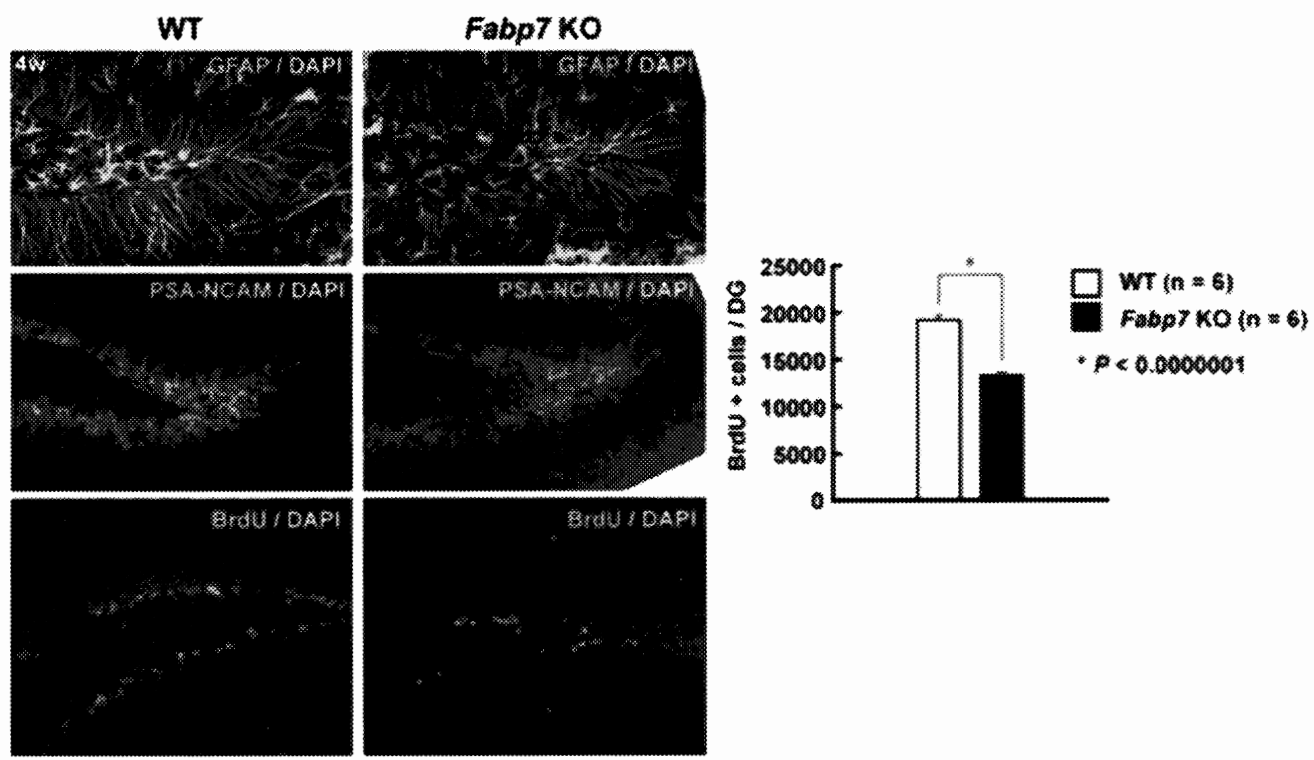

Figure 5. Neurogenesis in wild-type (WT) and Fabp7 knockout (KO) mice (Left) In the hippocampal dentate gyrus at 4 weeks, Fabp7-null mice show decreased expression of GFAP (a neural stem/early progenitor marker) and PSA-NCAM (a late progenitor marker).

(Right) The number of BrdU-incorporated cells is markedly reduced in Fabp7-null mice at 4 weeks, suggesting a dramatic decrease in the production of new neurons.

以上のことからFabp7とPPIの関連について推論すると、C3マウスはB6マウスに比 ベてFabp7の機能に何らかの低下があり、そのために感覚フィルター機能に関与する 脳の神経細胞ネットワークの発達段階で微細な機能低下が生じ、結果としてPPIの減 弱という表現型がみられると解釈できる。 


\section{7. ヒト統合失調症とFABP7遺伝子}

「統合失調症ではPPIが減弱している」「マウスのPPIを制御している遺伝子の1つが Fabp7である」というこれまでの結果から、ヒトFABP7遺伝子は果たして統合失調症 に関連があるのかどうか興味があるところである。FABP7遺伝子で報告されている一 塩基置換 (single nucleotide polymorphism: SNP) を用いて、統合失調症患者570例、 対照群570例で各SNPの対立遺伝子頻度を比較してみた。その結果、アミノ酸置換を 伴うSNP4（図6）が両群間で有意な頻度差があり、統合失調症の発症に関連があると
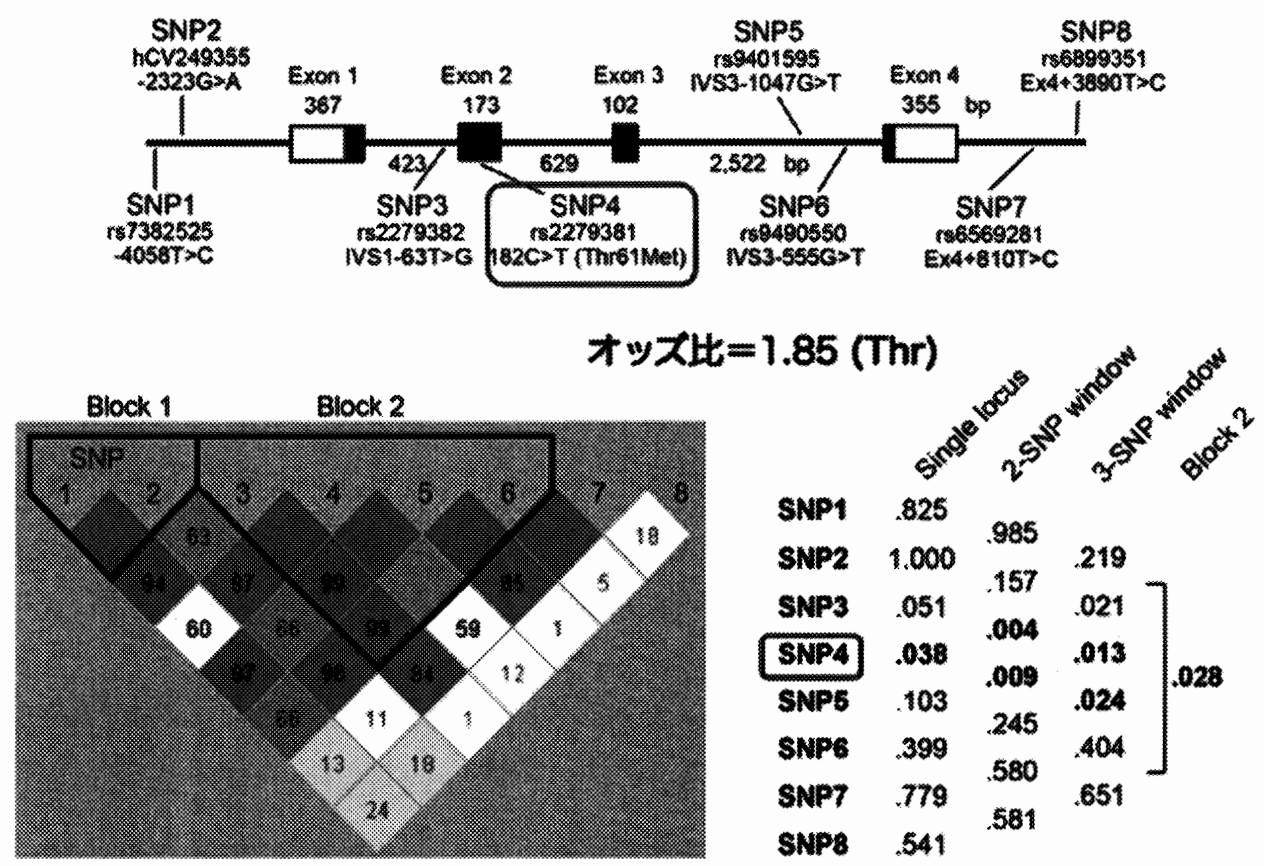

Figure 6. Genetic analysis of human $F A B P 7$

(Upper) Genomic structure and location of polymorphic sites in $F A B P 7$. Exons are denoted by boxes, with untranslated regions in white and translated regions in black. The sizes of exons and introns are also shown. 'rs' is an NCBI I.D. nomenclature (http://www.ncbi.nlm.nih.gov/) and ' $h C V$ ' is derived from the Celera Discovery System (https://www.appliedbiosystems.com/).

(Bottom left) The haplotype block pattern of the $F A B P 7$ interval is shown.

The number in each cell represents the linkage disequilibrium parameter $D^{\prime}(\mathrm{x} 100)$, red cells mean $D^{\prime}=1$. Each cell color is graduated relative to the strength of linkage disequilibrium between markers, which is defined by both the $D^{\prime}$ value and confidence bounds on $D^{\prime}$. Note that the FABP7 region consists of two haplotype blocks.

(Bottom right) Allelic $P$ values for single-locus and global $P$ values from multilocus (two, three and block 2) association analysis. Minor allele frequency data in control samples for individual SNPs were as follows: SNP1 $(\mathrm{C}=0.09), \mathrm{SNP} 2(\mathrm{~A}=0.34), \mathrm{SNP} 3(\mathrm{G}=0.36), \mathrm{SNP} 4(\mathrm{~T}=0.03), \mathrm{SNP} 5(\mathrm{G}=$ $0.38)$, SNP6 $(T=0.24), \operatorname{SNP7}(C=0.10), \operatorname{SNP8}(C=0.36)$. 
考えられた。また、SNP4を含むゲノム上のブロック2（図6）も統合失調症の発症に関 連がある結果であったので、SNP4の近傍に別の感受性SNPがある可能性、あるいは ブロック 2 内の複数のSNPの組み合わせが統合失調症に関連のある可能性も考えられ る。

\section{8. まとめ}

統合失調症の原因にはいろいろなものがあると考えるのが自然であるが、その中で も脳の発達期 (特に胎児期) に何らかの障害を受け、それによる微細な神経回路の障 害が疾患の脆弱性に関係しているという仮説（上述した「神経発達障害仮説」）は注目 されている。これを支持するエビデンスとしては、統合失調症の発症率を上昇させる以 下のような疫学的データがある：

（1）妊婦の栄盖不良

（2）妊婦のウィルス感染

（3）産科合併症、周産期障害

（4）母子間のRh血液型不適合

特に（1）に関しては、第二次世界大戦末期にオランダのアムステルダムで起こった Dutch Hunger Winterが有名である。アムステルダムはこの時期、ナチスドイツに陸路 を封鎖され極端な食糧不足に陥った。食糧配給は最悪の時期、約 $1,000 \mathrm{kcal}$ であった と言われている。それも殆ど炭水化物だけの支給であった。この飢饉の時期に妊娠し ていた子供が思春期に達したとき、統合失調症の発症率は約 2 倍になったという ${ }^{15)}$ 。 その後、1959-1961年にかけて中国全土を大飢饉が襲ったが、この時期に胎内にいた 子供が成人に達したときも、統合失調症の発症率はくしくも約 2 倍になったという報告 がある ${ }^{16)}$ 。このように、疫学デー夕からは「胎児期の栄養不良一統合失調症の発症基 盤形成」という図式が考えられるが、栄養素といっても非常に多数あり、またそのバラ ンスも重要なことは論を待たない。しかし、今回のデータからFABP7という分子を介し て多価不飽和脂肪酸が統合失調症の発症に寄与している可能性が示唆された。統合 失調症は一端発症すると根治（あるいは完治：寛解との違いに注意）するのが難しい 疾患であり、予防法の確立が重要と思われる。今後は、母体、あるいは生後早期の 時期の適正な多価不飽和脂肪酸の摄取が、将来の統合失調症の発症に予防効果を発 揮するかどうか、検討していくことが大切であると考えられる。 


\section{参考文献}

1. Gottesman I.I. Schizophrenia Genesis: The Origin of Madness, 1991, New York: W.H. Freeman.

2. News feature. The brains of the family. Nature 454: 154-157, 2008.

3. Gottesman I.I., Gould T.D. The endophenotype concept in psychiatry: etymology and strategic intentions. Am J Psychiatry 160: 636-645, 2003.

4. Cadenhead K.S., Swerdlow N.R., Shafer K.M., Diaz M., David L. Braff D.L. Modulation of the startle response and startle laterality in relatives of schizophrenic patients and in subjects with schizotypal personality disorder: evidence of inhibitory deficits. Am J Psychiatry 157: 1660 - 1668, 2000.

5. Watanabe A., Toyota T., Owada Y., Hayashi T., Iwayama Y., Matsumata M., Ishitsuka Y., Nakaya A., Maekawa M., Ohnishi T., Arai R., Sakurai K., Yamada K., Kondo H., Hashimoto K., Osumi N., Yoshikawa T. Fabp7 maps to a quantitative trait locus for a schizophrenia endophenotype. PLoS Biology 5: e297, 2007.

6. Xu L.Z., Sanchez R., Sali A., Heintz N. Ligand specificity of brain lipid-binding protein. J Biol Chem 271: 24711-24719, 1996.

7. Rapoport J.L., Addington A.M., Frangou S., Psych M.R. The neurodevelopmental model of schizophrenia: update 2005. Mol Psychiatry 10: 434-449, 2005.

8. Das U.N. Essential Fatty acids - a review. Curr Pharm Biotechnol 7: 467-482, 2006.

9. Liu R.Z., Li X., Godbout R. A novel fatty acid-binding protein (FABP) gene resulting from tandem gene duplication in mammals: transcription in rat retina and testis. Genomics 92: 436-445, 2008.

10. Haunerland N.H., Spener F. Fatty acid-binding proteins - insights from genetic manipulations. Prog Lipid Res 43: 328-349, 2004.

11. Mackay T.F.C. Complementing complexity. Nat Genet 36: 1145-1147, 2004.

12. Itokawa M., Yamada K., Yoshitsugu K., Toyota T., Suga T., Ohba H., Watanabe A., Hattori E., Shimizu H., Kumakura T., Ebihara M., Meerabux J.M.A., Toru M., Yoshikawa T. A microsatellite repeat in the promoter of the NMDA receptor 2A subunit (GRIN2A) gene suppresses transcriptional activity and correlates with chronic outcome in schizophrenia. Pharmacogenetics 13: 271-278, 2003.

13. Owada Y., Abdelwahab S.A., Kitanaka N., Sakagami H., Takano H., Sugitani 
Y., Sugawara M., Kawashima H., Kiso Y., Mobarakeh J.I., Yanai K., Kaneko K., Sasaki H., Kato H., Saino-Saito S., Matsumoto N., Akaike N., Noda T., Kondo H. Altered emotional behavioral responses in mice lacking brain-type fatty acid binding protein gene. Eur J Neurosci 24: 175-187, 2006.

14. Arai Y., Funatsu N., Numayama-Tsuruta K., Nomura T., Nakamura S., Osumi N. Role of Fabp7, a downstream gene of Pax6, in the maintenance of neuroepithelial cells during early embryonic development of the rat cortex. J Neurosci 25: 9752-9761, 2005.

15. Susser E.S., Lin S.P. Schizophrenia after prenatal exposure to the Dutch Hunger Winter of 1944-1945. Arch Gen Psychiatry 49: 983-988, 1992.

16. St Clair D., Xu M., Wang P., Yu Y., Fang Y., Zhang F, Zheng X, Gu N, Feng G, Sham P, He L. Rates of adult schizophrenia following prenatal exposure to the Chinese famine of 1959-1961. JAMA 294: 557-562, 2005. 